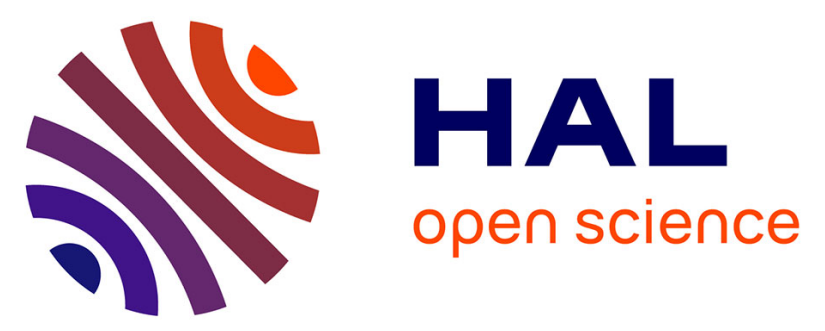

\title{
Adsorption of Quinolone Antibiotics to Goethite under Seawater Conditions: Application of a Surface Complexation Model
}

Wei Cheng, Elaheh Lotfi Kalahroodi, Remi Marsac, Khalil Hanna

\section{- To cite this version:}

Wei Cheng, Elaheh Lotfi Kalahroodi, Remi Marsac, Khalil Hanna. Adsorption of Quinolone Antibiotics to Goethite under Seawater Conditions: Application of a Surface Complexation Model. Environmental Science and Technology, 2019, 53 (3), pp.1130-1138. 10.1021/acs.est.8b04853 . hal-01964933

\section{HAL Id: hal-01964933 \\ https://hal.science/hal-01964933}

Submitted on 24 Dec 2018

HAL is a multi-disciplinary open access archive for the deposit and dissemination of scientific research documents, whether they are published or not. The documents may come from teaching and research institutions in France or abroad, or from public or private research centers.
L'archive ouverte pluridisciplinaire $\mathbf{H A L}$, est destinée au dépôt et à la diffusion de documents scientifiques de niveau recherche, publiés ou non, émanant des établissements d'enseignement et de recherche français ou étrangers, des laboratoires publics ou privés. 
Subscriber access provided by SCD Université de Rennes1 | SCD de l'Université de Rennes 1

Characterization of Natural and Affected Environments

\section{Adsorption of Quinolone Antibiotics to Goethite under Seawater Conditions: Application of a Surface Complexation Model}

Wei Cheng, Elaheh Lotfi Kalahroodi, Rémi Marsac, and Khalil Hanna

Environ. Sci. Technol., Just Accepted Manuscript • DOI: 10.1021/acs.est.8b04853 • Publication Date (Web): 21 Dec 2018

Downloaded from http://pubs.acs.org on December 24, 2018

\section{Just Accepted}

"Just Accepted" manuscripts have been peer-reviewed and accepted for publication. They are posted online prior to technical editing, formatting for publication and author proofing. The American Chemical Society provides "Just Accepted" as a service to the research community to expedite the dissemination of scientific material as soon as possible after acceptance. "Just Accepted" manuscripts appear in full in PDF format accompanied by an HTML abstract. "Just Accepted" manuscripts have been fully peer reviewed, but should not be considered the official version of record. They are citable by the Digital Object Identifier (DOI®). "Just Accepted" is an optional service offered to authors. Therefore, the "Just Accepted" Web site may not include all articles that will be published in the journal. After a manuscript is technically edited and formatted, it will be removed from the "Just Accepted" Web site and published as an ASAP article. Note that technical editing may introduce minor changes to the manuscript text and/or graphics which could affect content, and all legal disclaimers and ethical guidelines that apply to the journal pertain. ACS cannot be held responsible for errors or consequences arising from the use of information contained in these "Just Accepted" manuscripts. 


\section{Adsorption of Quinolone Antibiotics to Goethite under Seawater}

\section{Conditions: Application of a Surface Complexation Model}

aUniv Rennes, Ecole Nationale Supérieure de Chimie de Rennes, CNRS, ISCR - UMR6226, 


\section{ABSTRACT}

The assessment of antibiotics mobility under seawater conditions has been rarely studied, since an accurate description of such multicomponent systems is quite challenging. In this study, the adsorption of a widely used quinolone antibiotic in aquaculture, Oxolinic acid (OA), to a synthetic goethite $(\alpha-\mathrm{FeOOH})$ was examined in presence of major (e.g. $\left.\mathrm{Mg}^{2+}, \mathrm{SO}_{4}{ }^{2-}\right)$ and trace (e.g. $\mathrm{Cu}^{2+}$ ) ions naturally occurring in seawater. The OA adsorption can be successfully predicted using a charge distribution multi-site complexation model (CD-MUSIC) coupled with the three plane model (TPM). This modeling approach allowed a quantification of the competitive and synergetic effects of different ions in seawater over a large range of environmentally relevant conditions. In addition, the transport of OA in flow-through columns can be well predicted through coupling hydrodynamic parameters and surface complexation constants obtained under seawater conditions. These results may have strong implications for assessment and prediction of the fate of quinolones in sediment/seawater interface systems. 


\section{INTRODUCTION}

Quinolone antibiotics, broad-spectra antimicrobial agents, are widely used in the treatment and prevention of bacterial diseases of fish. ${ }^{1,2}$ Among them, Oxolinic Acid (OA) is commonly used as a prophylactic, or, as a chemotherapy agent. ${ }^{1,2}$ Due to its frequent use ${ }^{3}$, high residual levels of $\mathrm{OA}$ were detected in aquatic systems, i.e. in concentration ranging from $2.50 \mathrm{ppm}$ in fresh or saline surface waters to $426 \mathrm{ppm}$ in pond sediments. ${ }^{4-6}$ Because of the rapid growth of aquaculture in different countries, impacts of antibiotics overuse on the environment are becoming of big concern. ${ }^{7}$ Therefore, it is necessary to investigate the transport and mobility of quinolones in marine ecosystems, in order to accurately assess their ecological impacts.

In marine environments, mineral particles present in suspension or in sediments are able to bind quinolones, which may affect their mobility and bioavailability in water. ${ }^{8}$ Among these reactive mineral surfaces, goethite $(\alpha-\mathrm{FeOOH})$ is the most thermodynamically stable iron oxyhydroxide mineral and the most common diagenetic iron oxyhydroxide in both marine and lake sediments. ${ }^{9}$ Recently, goethite has been shown to strongly sorb OA across a wide range of salinity $(10-1000 \mathrm{mM} \mathrm{NaCl})$ including seawater-like one. ${ }^{8}$ However, cations and anions existing in seawater environments naturally or due to anthropogenic activities, could affect the mobility of OA in marine ecosystems. This may proceed through (i) complexation with divalent transition metals in aqueous solution ${ }^{10,11}$ and (ii) competitive or cooperative binding to mineral surfaces. ${ }^{12-16}$

Despite the widespread use of quinolones in fish farming, the effect of cations and anions found in seawater on their solubility and adsorption behavior to suspended mineral particles or mineral sediments has received little attention. In this study, interactions of OA with goethite in presence of two major ions (e.g. $\left.\mathrm{Mg}^{2+}, \mathrm{SO}_{4}{ }^{2-}\right)$ and one trace cation $\left(\mathrm{Cu}^{2+}\right.$ used as a model trace metal in seawater) have been studied under a wide range of ion concentrations and $\mathrm{pH}$ values. Possible antagonistic or synergetic effects on OA adsorption have also been 
investigated in presence of mixture of $\mathrm{Mg}^{2+}, \mathrm{SO}_{4}{ }^{2-}$ and $\mathrm{Cu}^{2+}$, and in synthetic seawater. The ability of the three plane model (TPM) to predict competitive or cooperative interactions on goethite surfaces has been evaluated under a wide range of $\mathrm{pH}$ (4-10). Finally, this thermodynamic adsorption model was used to predict the breakthrough behavior of $\mathrm{OA}$ in a goethite-packed column under water-saturated conditions.

Given the complexity of the seawater matrix where a wide array of cations and anions exist, a quantitative framework for assessing competitive or synergetic interactions both under static and hydrodynamic conditions is quite challenging. For the first time, TPM combined with the charge distribution-multisite complexation (CD-MUSIC) model is successfully applied to predict binding mechanisms of contaminants on mineral particles in the presence of major and trace ions of seawater, and then the reactive transport under flow-through conditions.

\section{MATERIALS AND METHODS}

2.1. Materials. All reagents were purchased from Sigma-Aldrich and used without further purification. All solutions were prepared with ultrapure water. An OA (purity $>99 \%$ ) stock solution was prepared by dissolving $30 \mathrm{mg}(115 \mu$ moles $) \mathrm{OA}$ in $20 \mathrm{~mL}$ of $1 \mathrm{M} \mathrm{NaOH}$, then diluted to $1 \mathrm{~L}$ with ultrapure water.

2.2. Synthesis and Characterization of Goethite Particles. Goethite was synthesized as described in previous studies. ${ }^{8,17}$ Briefly, $400 \mathrm{~mL}$ of a $2.5 \mathrm{~mol} \mathrm{~L}^{-1}$ sodium hydroxide solution was mixed with $500 \mathrm{~mL}$ of a $0.5 \mathrm{~mol} \mathrm{~L}^{-1}$ ferric nitrate solution $\left(\mathrm{Fe}\left(\mathrm{NO}_{3}\right)_{3} \cdot 9 \mathrm{H}_{2} \mathrm{O}\right)$ at a fixed rate of $1 \mathrm{~mL} \mathrm{~min}-1$ with stirring under nitrogen atmosphere. The obtained hydroxide slurry was aged at $60{ }^{\circ} \mathrm{C}$ for 72 hours in an oven. The precipitate obtained was then dialyzed (Spectra/Por membrane 2) against Milli-Q water. The water was changed every day until its conductivity was close to $0 \mu \mathrm{S} \mathrm{cm}^{-1}$. The suspensions were stored in polypropylene containers at $4{ }^{\circ} \mathrm{C}$ for further use. The purity of goethite was confirmed by X-ray diffraction (XRD) and 
the B.E.T. specific surface area of the synthetic goethite was $80 \pm 1 \mathrm{~m}^{2} \mathrm{~g}^{-1}$ and the point of zero charge (PZC) of goethite, determined under $\mathrm{N}_{2}$ atmosphere at $298 \mathrm{~K}$ in $0.01,0.1$ and $1 \mathrm{M}$ $\mathrm{NaCl}$ solutions by the potentiometric titration method, was $\mathrm{pH} 9.1$. Goethite coated sand (GCS) was prepared by coating goethite onto sieved Fontainebleau quartz sand $(100-150 \mu \mathrm{m})$ as previously detailed. ${ }^{18}$

2.3. Batch adsorption experiments. Because $\mathrm{pH}$ measurements will be affected by high background electrolyte solutions, the $\mathrm{pH}$ electrode was calibrated to measure the molarity of the proton $\left(-\log \left[\mathrm{H}^{+}\right]\right.$, noted as $\left.\mathrm{pHc}\right)$ using solutions of known $\left[\mathrm{H}^{+}\right]\left(10^{-5}-10^{-2} \mathrm{M}\right)$ in $480 \mathrm{mM}$ $\mathrm{NaCl}$, and the results are provided in this form in this study. The procedure was repeated in presence of other ions $\left(\mathrm{Mg}^{2+}, \mathrm{SO}_{4}{ }^{2-}, \mathrm{Cu}^{2+}\right)$.

OA solubility experiments (undersaturation direction) were conducted by suspending solid OA $(\sim 3-5 \mathrm{mg})$ in $10 \mathrm{~mL}$ of $480 \mathrm{mM} \mathrm{NaCl}$ with different concentrations of $\mathrm{Mg}^{2+}$ and adjusting pHc from 4 to 8 using $\mathrm{HCl}$ and $\mathrm{NaOH}$. The suspensions were equilibrated for $24 \mathrm{~h}$ (a sufficient time for assessing aqueous drug solubility ${ }^{19}$ ), after that the supernatants were filtered $(0.2 \mu \mathrm{m})$ and $\mathrm{OA}$ concentrations were measured with high pressure liquidchromatography coupled with UV detection (HPLC-UV).

All batch experiments were carried out under $\mathrm{N}_{2(\mathrm{~g})}$ atmosphere to avoid effects of carbonates and bicarbonates on the adsorption of $\mathrm{OA}$ onto goethite. Batch adsorption experiments were carried out in $15 \mathrm{~mL}$ polyethylene tubes at a total volume of $10 \mathrm{~mL}$ solution with $10 \mu \mathrm{M} \mathrm{OA}, 480 \mathrm{mM} \mathrm{NaCl}$ and $50 \mathrm{~m}^{2} \mathrm{~L}^{-1}$ goethite. $\mathrm{MgCl}_{2}(10$ and $50 \mathrm{mM}), \mathrm{CuCl}_{2}(10,50$ and $100 \mu \mathrm{M})$ and/or $\mathrm{Na}_{2} \mathrm{SO}_{4}(1,10$ and $29 \mathrm{mM})$ were added to the solutions in order to study the effects (and combined effects) of $\mathrm{Mg}^{2+}, \mathrm{SO}_{4}{ }^{2-}$ and/or $\mathrm{Cu}^{2+}$ on $\mathrm{OA}$ adsorption. The solution compositions of each experiment are listed in Table S1. The pHc was then adjusted to the desired value $(4<\mathrm{pHc}<10)$ with $\mathrm{HCl}$ or $\mathrm{NaOH}$ solutions. The tubes were sealed by caps and then shaken continuously on a platform shaker at $200 \mathrm{rpm}$ and $25^{\circ} \mathrm{C}$. After equilibrating for 
$24 \mathrm{~h}, \mathrm{pHc}$ was measured again before filtration $(0.2 \mu \mathrm{m})$ and OA was analyzed by HPLC-UV. Desorption tests $(\mathrm{pHc}=11)$ were carried out under various experimental conditions to check the mass balance of OA (Table S2).

To study OA adsorption in conditions closer to the marine environment, an artificial seawater was synthesized according to the method of Kester et al. ${ }^{20}$ Table S3 shows the major elements present in the synthetic seawater. However, batch experiments were conducted in absence of $\mathrm{NaHCO}_{3}$ in order to avoid the potential complication of competing carbonate adsorption.

Aqueous OA concentrations were determined using a high performance liquid chromatography (Waters 600 Controller) equipped with a UV detector (Waters 2489) and a reversed-phase $\mathrm{C} 18$ column $(250 \mathrm{~mm} \times 4.6 \mathrm{~mm}$ i.d., $5 \mu \mathrm{m})$. The mobile phase $\left(1 \mathrm{~mL} \mathrm{~min} \mathrm{~m}^{-1}\right)$ was a mixture of acetonitrile/water $(60: 40 \mathrm{v} / \mathrm{v})$ contained $0.1 \%$ formic acid. The detector was set to $259 \mathrm{~nm}$ for OA. Concentrations of $\mathrm{Cu}^{2+}$ and $\mathrm{Mg}^{2+}$ were analyzed by Varian AA140 Atomic Absorption Spectrometer. The sulfate concentration was measured by DIONEX IX Chromatograph DX-120.

2.4. Flow-through column experiments. Breakthrough column experiments were conducted according to Hanna et al. ${ }^{18,21}$ Briefly, $15 \mathrm{~g}$ of dry GCS was packed into glass chromatographic columns of $1.6 \mathrm{~cm}$ internal diameter to give a porous bed length of $4.7 \mathrm{~cm}$. After packing to a uniform bulk density $\left(1.59 \pm 0.05 \mathrm{~g} \mathrm{~cm}^{-3}\right)$, the column was wetted upward with a synthetic seawater solution at a constant flow rate. Once the column was water saturated, the flow characteristics of the porous bed were determined by a nonreactive tracer experiment, as previously described. ${ }^{18,21}$ The classical convection dispersion equation (CDE) was applied to describe the 1D transport of a non-reactive solute (bromide) under steady-state water flow. The fitting result provided estimations of the volumetric water content $(\theta)$ and dispersion coefficient (D) that characterize of flow homogeneity. The dispersivity $(\lambda)$ was 
132 calculated according to $\lambda=\mathrm{D} \theta / \mathrm{q}$, neglecting the molecular diffusion. At a flow rate of $0.5 \mathrm{~mL}$ $\min ^{-1}$, the Darcy velocity (q) was $0.25 \mathrm{~cm} \mathrm{~min}^{-1}$, the volumetric water content $\theta$ was found equal to $0.42 \mathrm{~cm}^{3} \mathrm{~cm}^{-3}$, water velocity $v=0.59 \mathrm{~cm} \mathrm{~min}^{-1}, \mathrm{D}=0.009 \mathrm{~cm}^{2} \mathrm{~min}^{-1}$ and $\lambda$ was 151 $\mu \mathrm{m}$ within order of magnitude of particle size of the used sand. The Péclet number $(\mathrm{Pe}=\nu \mathrm{L} / \mathrm{D}$, $\mathrm{L}$ is total column length) in the column was higher than 300 , indicating the predominance of a convective regime. Similarly, these parameters were also calculated for $0.1 \mathrm{~mL} \mathrm{~min}^{-1}$ as flow rate.

Two different conditions of inflow solution, with or without carbonates, were tested. In both tests, a mixture of $10 \mu \mathrm{M} \mathrm{OA}$ and $10 \mu \mathrm{M} \mathrm{Cu}^{2+}$ was injected in the column at a constant flow rate $\left(0.5 \mathrm{~mL} \mathrm{~min}^{-1}\right.$ or $\left.0.1 \mathrm{~mL} \mathrm{~min}^{-1}\right)$. OA concentrations in the collected fractions were measured by HPLC/UV.

2.5. Surface Complexation Modeling. Predictions of OA adsorption to goethite were made using the multisite complexation (MUSIC) model approach. ${ }^{22}$ The geochemical speciation code PHREEQC (version 2) ${ }^{23}$ was used for surface complexation calculations. The charge of the goethite/water interface was treated by using the three plane model (TPM). Charges of the adsorbates were distributed among the $0\left(\mathrm{H}^{+}\right.$, metal-bonded $\left.\mathrm{OA}\right), 1$ (hydrogenbonded $\mathrm{OA})$, and $2\left(\mathrm{Na}^{+}, \mathrm{Cl}^{-}\right)$planes of the TPM. Although not required for OA binding to goethite, ${ }^{8}$ a charge distribution (CD) term was used in the present work to describe the adsorption of other ions on goethite. Singly $\left(\equiv \mathrm{FeOH}^{-0.5}\right)$, doubly $\left(\equiv \mathrm{Fe}_{2} \mathrm{OH}\right)$ and triply $\left(\equiv \mathrm{Fe}_{3} \mathrm{O}^{-}\right.$ 0.5 and $\equiv \mathrm{Fe}_{3} \mathrm{OH}^{+0.5}$ ) coordinated oxygens outcrop the goethite surface, depending on the crystal face. A simplified 1-pK surface charging model, neglecting the contributions of doubly- and part of the triply-coordinated oxygens, was used. The reactive site density in this model are detailed in $\mathrm{SI}^{8}\left[\equiv \mathrm{FeOH}^{-0.5}\right]=3.12$ sites $\mathrm{nm}^{-2}$ and $\left[\equiv \mathrm{Fe}_{3} \mathrm{O}^{-0.5}\right]=3.12$ sites $\mathrm{nm}^{-2}$ on $(001) /(101)$ planes $\left(90 \%\right.$ of the surface area), and $\left[\equiv \mathrm{FeOH}^{-0.5}\right]=7.4$ sites $\mathrm{nm}^{-2}$ on $(021)$ plane (10\% of the surface area). The protonation constants of these groups are set to that of the 
pHpzc (1-pK approach of MUSIC model). Equilibrium constants of the formation of all surface species are reported in Table 1. PhreePlot $^{24}$ was used to determine parameters for OA sorption to goethite. Parameters describing goethite surface (e.g. $\mathrm{pK}_{\mathrm{a}}$, capacitances) and OAgoethite binding were taken from our previous work. ${ }^{8}$

PHREEQC can use various equations to account for the non-ideality of aqueous solutions. In this study, a modified version of the Debye-Hückel equation, called WATEQ, was used with the "minteq.v4" database provided with PHREEQC:

$\log \gamma_{i}=-\frac{A z_{i}^{2} \sqrt{I}}{1+B a_{i}^{0} \sqrt{I}}+b_{i} I$

Where $\gamma_{i}$ and $z_{i}$ are, respectively, the activity coefficient and the charge of the ion $i, \mathrm{~A}$ and $\mathrm{B}$ are temperature dependent parameters $\left(\mathrm{A}=0.5095\right.$ and $\mathrm{B}=0.3284 \times 10^{8}$ at $\left.25^{\circ} \mathrm{C}\right), a_{i}^{0}$ and $b_{i}$ are fitted ion-specific parameters. This equation is valid up to ionic strength (I) values of about 2 $\mathrm{M}$ in dominantly chloride solutions. ${ }^{25}$ Because these parameters are missing for OA aqueous species, $B a_{i}^{0}$ was systematically set to 1.5 (i.e., $a_{i}^{0}=4.57 \times 10^{-8}$ ), as commonly adopted in the specific ion interaction theory $\left(\mathrm{SIT}^{26}\right)$, a more advance model than the WATEQ equation. All necessary parameters are available in the "minteq.v4" database except for OA species. $b_{O A^{-}}=$ $b_{O A H}=0$ was used, as in our previous study. ${ }^{8} b_{O A M g}+$ was fitted using Phreeplot and OA solubility data in presence of $\mathrm{Mg}^{2+} . b_{O A C u}+$ and $b_{O A C a^{+}}$were assumed equal to $b_{O A M g^{+}}$.

All studied ions were included in the calculations, and PHREEQC calculates the ionic strength according to the solution composition. As shown below, surface complexations of almost all ions were taken into account except $\mathrm{Br}^{-}$and $\mathrm{H}_{3} \mathrm{BO}_{3}$. $\mathrm{Br}^{-}$is expected to behave similarly to $\mathrm{Cl}^{-}$, but is about 660 times less abundant than $\mathrm{Cl}^{-}$in seawater. To our knowledge, no CD-MUSIC parameters are available to describe $\mathrm{H}_{3} \mathrm{BO}_{3}$ sorption to goethite. Therefore, the adsorption of $\mathrm{Br}^{-}$and $\mathrm{H}_{3} \mathrm{BO}_{3}$ was neglected as a first approach. 
Precipitations of $\mathrm{Mg}(\mathrm{OH})_{2(\mathrm{~s})}, \mathrm{Ca}(\mathrm{OH})_{2(\mathrm{~s})}$ and $\mathrm{Cu}(\mathrm{OH})_{2(\mathrm{~s})}$ were taken into account in the calculations. Only $\operatorname{Mg}(\mathrm{OH})_{2(\mathrm{~s})}$ could form under alkaline conditions, which had little effect on the adsorption behavior and interpretations.

PhreePlot $^{24}$ was used when parameter adjustment was required. It also provides a statistical uncertainty for the estimated parameters (see Table 1). Parameters were fitted separately from independent datasets in simple (binary) systems, and then kept constant for simulations in more complex systems. For instance, $b_{O A M g}+$ was determined using OA solubility data in presence of $\mathrm{Mg}^{2+}$ and kept constant afterwards. Goethite-OA and goethite$\mathrm{Mg}^{2+}$ surface complexation constants were determined in previous studies dedicated to the corresponding binary system. ${ }^{8,27}$ Then, simulations were made (with no parameter adjustment) in the ternary goethite- $\mathrm{Mg}^{2+}-\mathrm{OA}$ system. This step-by-step procedure was used in all systems, hence limiting the uncertainties on newly adjusted model parameters.

$\mathrm{OAH}_{(\mathrm{aq})} \rightleftharpoons \mathrm{OA}^{-}+\mathrm{H}^{+} ; \log \mathrm{K}_{\mathrm{a}}=6.92$

The experimental solubility values are very close to the calculated ones (Figure S-1a). In $480 \mathrm{mM} \mathrm{NaCl}$, OA solubility increased with $\mathrm{pH}$ increasing.

OA adsorption shows typical anion adsorption character on goethite surfaces, i.e. adsorption reaches a maximum value at acidic to circumneutral $\mathrm{pH}$ and then decreases with 204 increasing $\mathrm{pH}$ (Figure S-1b). ${ }^{8}$ According to previous infrared spectroscopic investigations, ${ }^{8}$ 
OA binds to goethite predominantly through a metal-bonded (MB) complexes with surface Fe sites and a strong hydrogen-bonded (HB) complexes (surface hydration shared ion pair) with surface hydroxo groups. MB surface complex formed at the goethite $(101) /(001)$ and $(210)$ planes involving OA keto group and one oxygen of the carboxylate group:

$2 \mathrm{H}^{+}+2 \equiv \mathrm{FeOH}^{-0.5}+\mathrm{OA}^{-} \rightleftharpoons(\equiv \mathrm{Fe})_{2}(\mathrm{OA})^{0}+2 \mathrm{H}_{2} \mathrm{O} ; \quad \log \mathrm{K}_{\mathrm{MB}}$

Only singly coordinated $\left(=\mathrm{FeOH}^{-0.5}\right)$ surface sites are considered to be involved in the reaction given the propensity for ligand exchange of these sites. Eq.4 does not denote the number of $\mathrm{Fe}(\mathrm{III})$ octahedra in a complex but only the number of $\equiv \mathrm{FeOH}^{-0.5}$ sites that may or may not be of the same Fe(III) octahedron. ${ }^{28}$ Ideally, the steric constraints at the dominant (101)/(001) planes should promote bridging between two Fe atoms separated by $3 \AA$ from one another, ${ }^{29}$ while at the (210) plane, two $\equiv \mathrm{FeOH}^{-0.5}$ should be located on the same Fe(III) octahedron, hence our preference for modeling $\mathrm{OA}$ binding as a 1:2 $\mathrm{OA} / \equiv \mathrm{FeOH}^{-0.5}$ species.

Hydrogen-bonded (HB) complexation with singly $\equiv \mathrm{FeOH}^{-0.5}$ sites was also proposed:

$2 \mathrm{H}^{+}+2 \equiv \mathrm{FeOH}^{-0.5}+\mathrm{OA}^{-} \rightleftharpoons\left(\equiv \mathrm{FeOH}_{2}\right)_{2}{ }^{+1+\Delta \mathrm{z} 0 \ldots}(\mathrm{OA})^{\Delta \mathrm{zz} 1} ; \quad \log \mathrm{K}_{\mathrm{HB}}$

In our previous work, ${ }^{8}$ the $\mathrm{CD}$ approach was not used and OA negative charge was placed at the 1-plane $\left(\Delta z_{0}=0 ; \Delta z_{1}=-1\right)$. In general, within the CD-MUSIC framework, 0.2 bond valence unit can be assigned to each $\mathrm{H}$-bond. ${ }^{30}$ Because OA binds to goethite surface via two $\mathrm{H}$-bonds (one with each of two adjacent $\equiv \mathrm{FeOH}_{2}{ }^{+0.5}$ sites), a CD value of 0.4 was used $\left(\Delta \mathrm{z}_{0}=\right.$ $\left.-0.4 ; \Delta z_{1}=-0.6\right)$. In fact, this had minor effect on the prediction of OA-goethite binding and as shown in Figure S-1b, the model predicts well OA adsorption onto goethite at high salt concentration (i.e. $480 \mathrm{mM} \mathrm{NaCl}$ ).

\subsection{Effect of $\mathrm{Mg}^{2+}$ on $\mathrm{OA}$ solubility and binding to goethite}

The equilibrium constant of the formation of the aqueous $\mathrm{OAMg}^{+}$complex has previously been reported at $\mathrm{I}=0.1 \mathrm{M}:{ }^{10}$ 
In the present study, Mg-OA complexation in $480 \mathrm{mM} \mathrm{NaCl}$ was investigated via measurements of OA solubility at different $\mathrm{MgCl}_{2}$ concentrations (Figure 1a). As expected, OA apparent solubility increased with increasing $\left[\mathrm{Mg}^{2+}\right]$ due to the formation of $\mathrm{OAMg}^{+}$ aqueous complex. The formation constant of $\mathrm{OAMg}^{+}$was determined at infinite dilution (log $\mathrm{K}_{\mathrm{OA}-\mathrm{Mg}}=3.51$ ) using previously reported constant at $\mathrm{I}=0.1 \mathrm{M} \cdot{ }^{10}$. An accurate prediction of OA apparent solubility in presence of $\mathrm{Mg}^{2+}$ (Figure 1a) can be achieved by adjusting $b_{O A M g^{+}}$ (=0.5) using Phreeplot.

Figure $1 \mathrm{~b}$ shows $\mathrm{OA}$ adsorption to goethite in $480 \mathrm{mM} \mathrm{NaCl}$ at different $\mathrm{Mg}^{2+}$ concentrations $(0,10$ and $50 \mathrm{mM})$. The presence of $\mathrm{Mg}^{2+}$ decreased OA adsorption to goethite at all $\mathrm{pH}$ values and shifted the sorption edge to lower $\mathrm{pH}$ values. As previously reported, ${ }^{12,13}$ the effect of $\mathrm{Mg}^{2+}$ could be explained by the formation of an aqueous complex and/or competition effects towards surface sites. $\mathrm{Mg}^{2+}$ adsorption to goethite is weak and could not be accurately determined at a $\mathrm{Mg}^{2+}$ concentration as high as that used in the present work. This is also in agreement with a previous report, ${ }^{30}$ where $\mathrm{Mg}^{2+}$ adsorption became only detectable at $\mathrm{pH}>8$ and at lower $\left[\mathrm{Mg}^{2+}\right](\leqslant 0.4 \mathrm{mM})$ in $0.1 \mathrm{M} \mathrm{NaNO}_{3}$. At such $\mathrm{pH}$ value,

247 there is almost no OA adsorption in our experiments, ruling out possible competitive effect 248 with $\mathrm{Mg}^{2+}$. Accounting for $\mathrm{OAMg}^{+}$formation in the $\mathrm{OA}$ adsorption model agreed with our experimental values. Including $\mathrm{Mg}^{2+}$-goethite surface complexation ${ }^{30}$ did not affect the simulations, thereby confirming the predominant contribution of the aqueous complex 

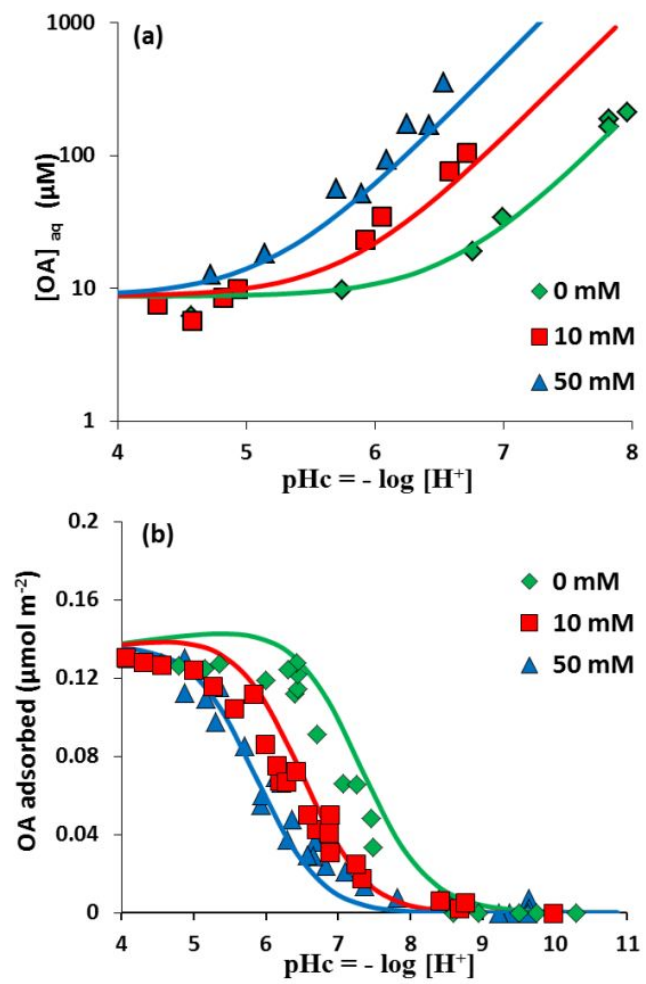

Figure 1. (a) $\mathrm{OA}$ solubility in $480 \mathrm{mM} \mathrm{NaCl}$ at different $\mathrm{MgCl}_{2}$ concentrations. (b) $\mathrm{OA}$ (10 $\mu \mathrm{M})$ adsoption to goethite $\left(50 \mathrm{~m}^{2} \mathrm{~L}^{-1}\right)$ in $480 \mathrm{mM} \mathrm{NaCl}$ versus $\mathrm{pHc}$ at different $\mathrm{MgCl}_{2}$ concentrations after $24 \mathrm{~h}$ reaction time. Lines are modeling results.

\subsection{Effect of $\mathrm{SO}_{4}{ }^{2-}$ on $\mathrm{OA}$ binding to goethite}

Figure 2a shows $\mathrm{OA}$ adsorption to goethite at different $\mathrm{SO}_{4}{ }^{2-}$ concentrations $(0,1,10$ and $29 \mathrm{mM})$. At $1 \mathrm{mM}$ of $\mathrm{SO}_{4}{ }^{2-}$, there is almost no effect on $\mathrm{OA}$ adsorption. For larger $\left[\mathrm{SO}_{4}{ }^{2-}\right.$, OA adsorption is only decreased at low $\mathrm{pH}$ values $(\mathrm{pHc}<6.5)$, with no significant influence at higher $\mathrm{pH}$ (Figure 2a).

To maximize sensitivity to residual sulfate concentration determination, $\mathrm{SO}_{4}{ }^{2-}$ adsorption was only determined at the lowest $\left[\mathrm{SO}_{4}{ }^{2-}\right]$ (i.e. $1 \mathrm{mM}$ ). Because ionic chromatography measurements of aqueous $\left[\mathrm{SO}_{4}{ }^{2-}\right]$ are subjected to large error due to interferences caused by $\mathrm{Cl}^{-}$, adsorption experiment was investigated at both 10 and $480 \mathrm{mM} \mathrm{NaCl}$ concentrations (Figure 2b). As typically observed for anion adsorption to iron oxides, sulfate adsorption decreased with increasing $\mathrm{pH}^{31-34}$ According to several vibrational spectroscopy 
studies, ${ }^{32,35,36}$ both inner-sphere complexes and outer-sphere complexes are supposed to form

268 between $\mathrm{SO}_{4}{ }^{2-}$ and the goethite surface. Therefore, a monodentate MB complex (eq.7) and a monodentate HB surface (eq.8) complex can be proposed to describe the adsorption data as following: 37 between the 1- and 2-plane for the HB complex. By fitting only the surface complexation constants in the present investigation (see Table 1), our model satisfactorily described sulfate adsorption versus $\mathrm{pH}$ and ionic strength (Figure 2b). By keeping these new parameters constants, the model successfully predicted competitive effect of sulfate on $\mathrm{OA}$ at $\mathrm{pH}<7$, but underestimated OA adsorption at higher $\mathrm{pH}$ values (Figure 2a). This experimental and modeling data confirm the sulfate competition for OA adsorption at low $\mathrm{pH}$ values.
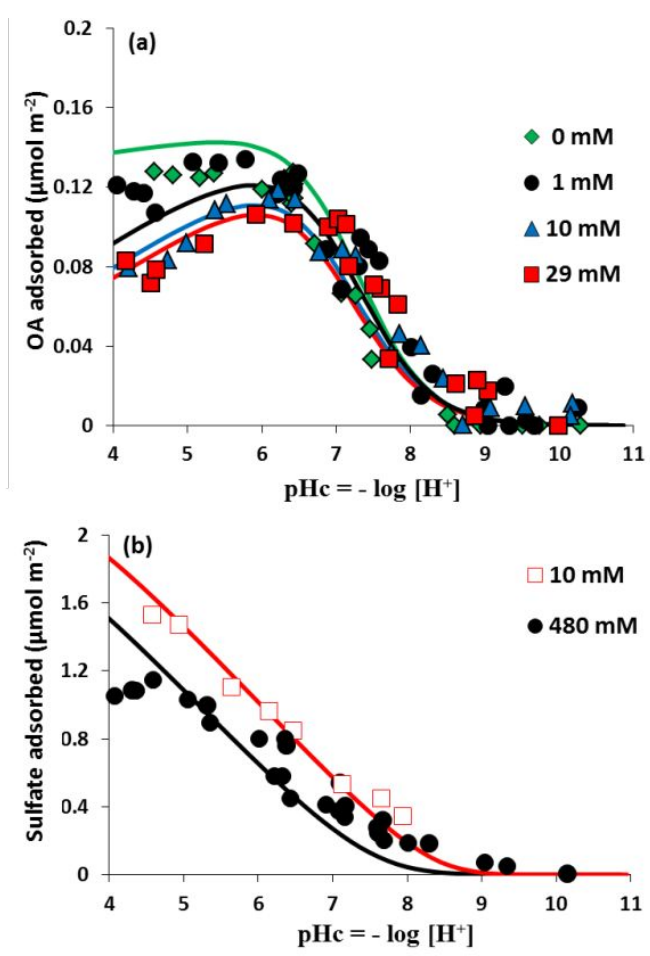
$\mathrm{NaCl}$ versus $\mathrm{pHc}$ at different $\mathrm{Na}_{2} \mathrm{SO}_{4}$ concentrations and (b) Sulfate removal for $\left[\mathrm{Na}_{2} \mathrm{SO}_{4}\right]=1$ $\mathrm{mM}$ and $[\mathrm{OA}]_{\text {tot }}=10 \mu \mathrm{M}$ at two $\mathrm{NaCl}$ concentrations on $50 \mathrm{~m}^{2} \mathrm{~L}^{-1}$ goethite versus $\mathrm{pHc}$ after $24 \mathrm{~h}$ reaction time. Lines are modeling results.

\subsection{Effect of $\mathrm{Cu}^{2+}$ on $\mathrm{OA}$ binding to goethite}

The equilibrium constant of the formation of the aqueous $\mathrm{OACu}^{+}$complex has been reported to be much larger than that of $\mathrm{OAMg}^{+}$complex at $\mathrm{I}=0.1 \mathrm{M}:{ }^{10}$

$\mathrm{OA}^{-}+\mathrm{Cu}^{2+} \rightleftharpoons \mathrm{OACu}^{+} ; \log \mathrm{K}_{\mathrm{OA}-\mathrm{Cu}}$

By using the WATEQ equation and setting $b_{O A C u^{+}}=b_{O A M g^{+}}=0.5, \log \mathrm{K}_{\mathrm{OA}-\mathrm{Cu}}$ was found equal to 6.61. Figure 3a shows that copper adsorption to goethite increases with $\mathrm{pH}$, for the three tested concentrations $(10,50$ and $100 \mu \mathrm{M})$. Based on previous report, ${ }^{38}$ four equations can be proposed to describe the binding of $\mathrm{Cu}^{2+}$ to goethite:

$2 \equiv \mathrm{FeOH}^{-0.5}+\mathrm{Cu}^{2+} \rightleftharpoons(\equiv \mathrm{FeOH})_{2}{ }^{-1+\Delta \mathrm{z} 0} \mathrm{Cu}^{\Delta \mathrm{z} 1} ; \log \mathrm{K}_{(\equiv \mathrm{FeOH})_{2} \mathrm{Cu}}$

$2 \equiv \mathrm{FeOH}^{-0.5}+\mathrm{Cu}^{2+}+\mathrm{H}_{2} \mathrm{O} \rightleftharpoons(\equiv \mathrm{FeOH})_{2}{ }^{-1+\Delta z 0} \mathrm{Cu}(\mathrm{OH})^{\Delta \mathrm{z} 1-1}+\mathrm{H}^{+} ; \quad \log \mathrm{K}_{(=\mathrm{FeOH})_{2} \mathrm{Cu}(\mathrm{OH})}$

$2 \equiv \mathrm{FeOH}^{-0.5}+2 \mathrm{Cu}^{2+}+2 \mathrm{H}_{2} \mathrm{O} \rightleftharpoons(\equiv \mathrm{FeOH})_{2}{ }^{-1+\Delta z 0} \mathrm{Cu}_{2}(\mathrm{OH})_{2}{ }^{\Delta \mathrm{z} 1}+2 \mathrm{H}^{+} ; \log \mathrm{K}_{\left(\equiv \mathrm{FeOH}_{2} \mathrm{Cu}_{2}(\mathrm{OH})_{2}\right.}$

$2 \equiv \mathrm{FeOH}^{-0.5}+2 \mathrm{Cu}^{2+}+3 \mathrm{H}_{2} \mathrm{O} \rightleftharpoons(\equiv \mathrm{FeOH})_{2}{ }^{-1+\Delta \mathrm{z} 0} \mathrm{Cu}_{2}(\mathrm{OH})_{3}{ }^{\Delta \mathrm{zl}-1}+3 \mathrm{H}^{+} ; \log \mathrm{K}_{\left(\equiv \mathrm{FeOH}_{2} \mathrm{Cu}_{2}(\mathrm{OH})_{3}\right.}$

Using this model, our $\mathrm{Cu}^{2+}$ uptake data in $480 \mathrm{mM} \mathrm{NaCl}$ can be well predicted by only adjusting $\log \mathrm{K}(\equiv \mathrm{FeOH})_{2} \mathrm{Cu}(\mathrm{OH})$ (eq.11), while keeping all other parameters equal to literature values. $^{31}$

The presence of $\mathrm{Cu}^{2+}$ significantly enhanced $\mathrm{OA}$ adsorption at all $\mathrm{pH}$ values, whereas $\mathrm{OA}$ adsorption increased with increasing $\mathrm{Cu}^{2+}$ concentration (Figure 3b). As previously reported, ${ }^{14,38-41}$ the formation of a surface- $\mathrm{Cu}^{2+}$-organic ligand ternary complex may explain the enhancement in $\mathrm{OA}$ adsorption. Indeed, $\mathrm{Cu}^{2+}$ may act as a bridge ion to form a sixmember ring with the carboxylic and carbonyl groups. ${ }^{39}$ Accordingly, accounting for a ternary 
goethite- $\mathrm{Cu}^{2+}$-OA complex (eq.14) allows an accurate prediction of OA binding to goethite in presence of $\mathrm{Cu}^{2+}$ (Figure 3b):

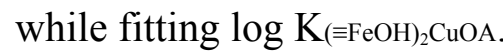
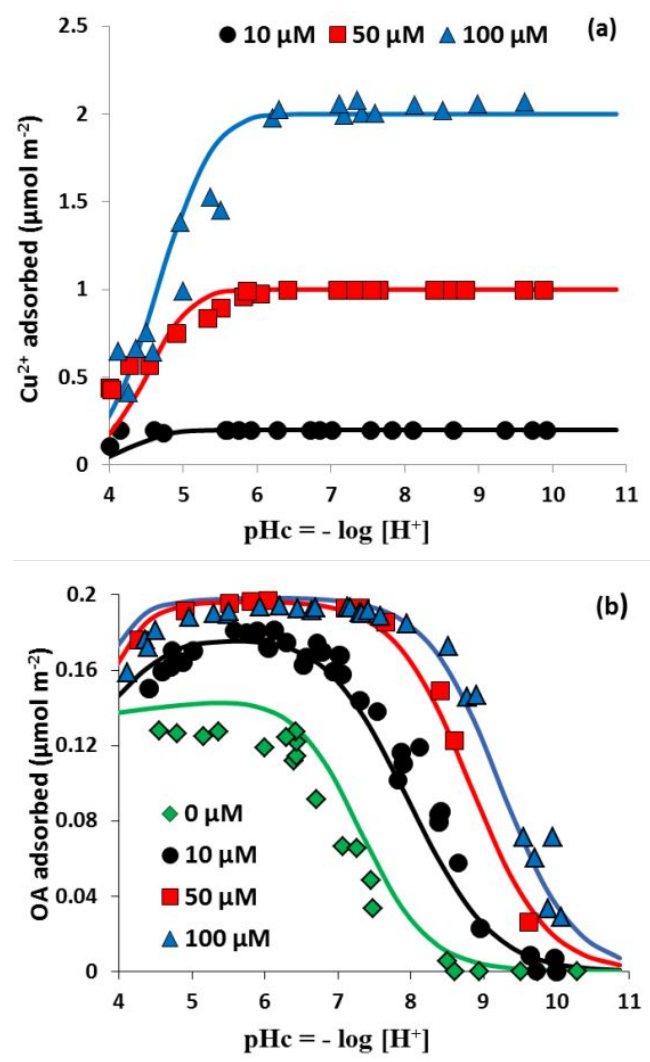

Figure 3. (a) $\mathrm{Cu}^{2+}$ and (b) $\mathrm{OA}$ removal from solutions for $[\mathrm{OA}]_{\text {tot }}=10 \mu \mathrm{M}$ on $50 \mathrm{~m}^{2} \mathrm{~L}^{-1}$ goethite in $480 \mathrm{mM} \mathrm{NaCl}$ versus $\mathrm{pHc}$ at different $\mathrm{CuCl}_{2}$ concentrations after $24 \mathrm{~h}$ reaction time. Lines are modeling results.

\subsection{OA-goethite binding in presence of $\mathrm{Mg}^{2+}, \mathrm{SO}_{4}{ }^{2-}$ and $\mathrm{Cu}^{2+}$}

As shown in Figure 4a, OA-goethite $\mathrm{pH}$-edge in presence of mixture of $\mathrm{Mg}^{2+}$ and $\mathrm{SO}_{4}{ }^{2-}$ exhibits the previously observed features, i.e. $\mathrm{Mg}^{2+}$ decreased OA adsorption and shifted sorption edge to lower $\mathrm{pH}$, while $\mathrm{SO}_{4}{ }^{2-}$ decreased only significantly $\mathrm{OA}$ adsorption at low $\mathrm{pH}$ 
319 values. Interestingly, our SCM has well predicted the experimental data without further parameter adjustment.

As expected, the presence of $10 \mu \mathrm{M} \mathrm{Cu}^{2+}$ increased OA-goethite binding even in presence

(Figure S-2a) and underestimated $\mathrm{Cu}^{2+}$ (Figure $\mathrm{S}-2 \mathrm{~b}$ ) adsorption to goethite at low $\mathrm{pH}$, respectively. As an attempt to improve the description of our experimental data, we include a ternary surface goethite-Cu-sulfate complex in the present model (applying the same fitting procedure as for the goethite-Cu-OA complex), as previously suggested: ${ }^{43}$

We assumed that $\mathrm{Cu}^{2+}$ charge is located at the 0 plane and charge distribution of $\mathrm{SO}_{4}{ }^{2-}$ is similar to that of MB complex in eq. 7 (i.e. -0.5 charge at the 0 -plane, -1.5 at the 1 -plane).This equation has permitted to enhance $\mathrm{Cu}$-goethite binding and limit the goethite-Cu-OA surface and $\mathrm{OA}$ adsorption to goethite (Figure $4 \mathrm{~b}$ ).
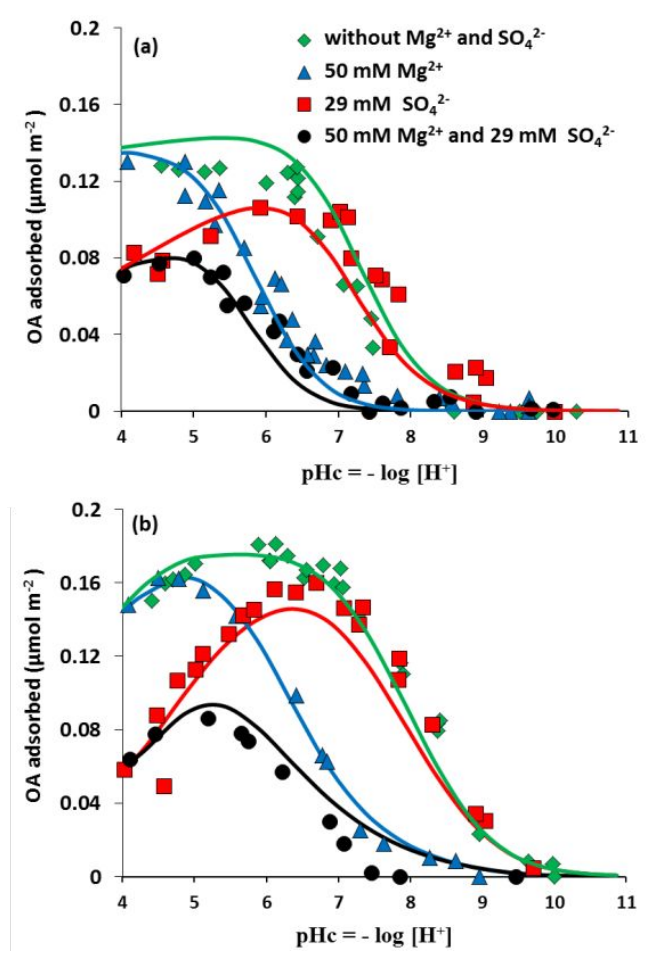
Figure 4. OA removal from solutions for $[\mathrm{OA}]_{\mathrm{tot}}=10 \mu \mathrm{M}$ on $50 \mathrm{~m}^{2} \mathrm{~L}^{-1}$ goethite in $480 \mathrm{mM}$

335

336 $\mathrm{NaCl}$ versus $\mathrm{pHc}$ at $50 \mathrm{mM} \mathrm{MgCl}_{2}$ and /or $29 \mathrm{mM} \mathrm{Na}_{2} \mathrm{SO}_{4}$ after $24 \mathrm{~h}$ reaction time in presence of (a) $0 \mu \mathrm{M} \mathrm{CuCl}_{2}$ (b) $10 \mu \mathrm{M} \mathrm{CuCl}_{2}$. Lines are modeling results. Same legends for (a) and (b).

It is worth noting that no further parameter adjustment was made in the following sections, which aim at testing the capability of the present model to predict OA adsorption and transport under conditions closer to marine environments.

\subsection{OA adsorption in synthetic seawater}

OA adsorption edges in synthetic seawater is similar to that obtained in presence of 50 $\mathrm{mM} \mathrm{MgCl}$ and $29 \mathrm{mM} \mathrm{Na}_{2} \mathrm{SO}_{4}$ at $480 \mathrm{mM} \mathrm{NaCl}$ (Figure S-3), suggesting that $\mathrm{Mg}^{2+}$ and $\mathrm{SO}_{4}{ }^{2-}$ are the most influencing ions in synthetic seawater investigated here. Other ions such as $\mathrm{F}^{-}, \mathrm{Br}^{-}, \mathrm{BO}_{3}{ }^{3-}$ and $\mathrm{Ca}^{2+}$ have no significant impact on $\mathrm{OA}$ adsorption due to their lower concentrations in synthetic seawater. When the aqueous complexation of $\mathrm{Ca}^{2+}$ and $\mathrm{OA}:{ }^{10}$

$\mathrm{OA}^{-}+\mathrm{Ca}^{2+} \rightleftharpoons \mathrm{OACa}^{+} ; \log \mathrm{K}_{\mathrm{OA}-\mathrm{Ca}}$

and surface complexation of $\mathrm{Ca}^{2+}$ to goethite ${ }^{30}$ and $\mathrm{F}^{-}$to goethite ${ }^{44}$ are introduced in the present model (see more details in Table 1), only a slight difference in the predicted OAgoethite binding is observed, as compared to that simulated in presence of only $\mathrm{Mg}^{2+}$ and $\mathrm{SO}_{4}{ }^{2-}($ Figure S-3).

The presence of $\mathrm{Cu}^{2+}$ in synthetic seawater overrides partially the negative effects of major ions and, thus, increased OA adsorption (Figure 5). $\mathrm{Cu}^{2+}$ adsorption to goethite in seawater or in presence of $50 \mathrm{mM} \mathrm{MgCl}$ and $29 \mathrm{mM} \mathrm{Na}_{2} \mathrm{SO}_{4}$ at $480 \mathrm{mM} \mathrm{NaCl}$ did not exhibit a significant difference (Figure S-4). The model predicted quite well OA and $\mathrm{Cu}^{2+}$ adsorption to goethite in seawater without further parameter adjustment (Figure 5 and Figure S-4). 


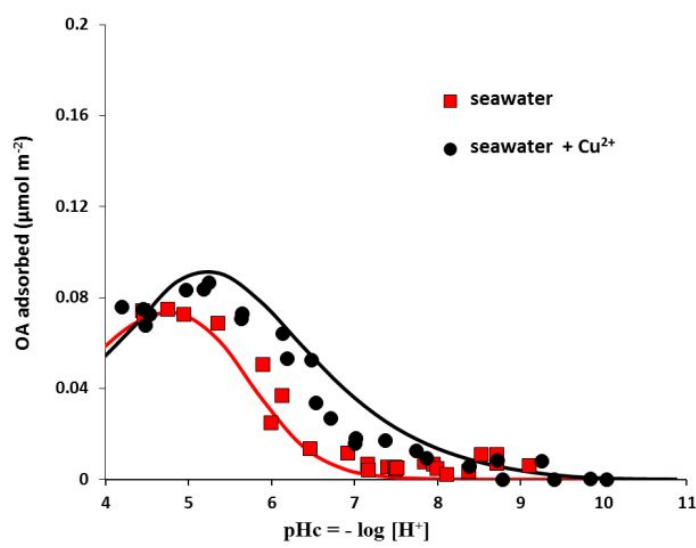

Figure 5. OA removal from synthetic seawater for $[\mathrm{OA}]_{\text {tot }}=10 \mu \mathrm{M}$ on $50 \mathrm{~m}^{2} \mathrm{~L}^{-1}$ goethite versus $\mathrm{pHc}$ with or without $10 \mu \mathrm{M} \mathrm{CuCl}_{2}$ after $24 \mathrm{~h}$ reaction time. Lines are modeling results.

\subsection{OA transport under seawater conditions}

In order to assess the OA binding to goethite surfaces under flow-through conditions, dynamic experiments were carried out using goethite-coated sand (GCS) packed column. Column saturation has been made using synthetic seawater to emulate water-saturated marine sediments.

In a first experiment, the column was injected with $10 \mu \mathrm{M} \mathrm{OA}$ and $10 \mu \mathrm{M} \mathrm{Cu}^{2+}$ dissolved in synthetic seawater as used in batch experiments (Table S-3 without carbonates), at a water velocity of $0.5 \mathrm{~mL} \mathrm{~min}{ }^{-1}$. The $\mathrm{pH}$ of inflow solution lied at $7.4 \pm 0.1$, and then slightly increased in the column system (exp1- $0.5 \mathrm{~mL} \mathrm{~min}^{-1}$ in Figure 6a). The total adsorbed amount at complete OA breakthrough $\left(\sim 0.03 \mu \mathrm{mol} \mathrm{m} \mathrm{m}^{-2}\right)$ is close to that expected from the batch experiments (Figure 5). However, the predicted breakthrough using batch-derived parameters overestimated OA sorption in the column system and showed a large retardation (see Figure 6b). The fast $\mathrm{OA}$ transportation at $0.5 \mathrm{~mL} \mathrm{~min} \mathrm{~m}^{-1}$ could possibly be related to the lack of local geochemical equilibrium in the column, as previously observed in numerous reports. ${ }^{21,45-48}$ The steepness of the BTC of OA as compared to that of bromide (i.e. the BTC of OA is more tilted than that of the tracer) as well as the short tail observed in the BTC of OA suggests that sorption kinetic limitations might take place in the column. In order to test this possibility, an 
additional flow-through experiment was performed at a lower flow rate $\left(0.1 \mathrm{~mL} \mathrm{~min}^{-1}\right)$ using the same conditions of $\exp 1$ (i.e. $10 \mu \mathrm{M} \mathrm{OA}, 10 \mu \mathrm{M} \mathrm{Cu}^{2+}, \mathrm{pH}_{\text {in }} 7.4 \pm 0.1$ ) (Figure 6a). The experimental breakthrough curve becomes more sigmoidal in shape at $0.1 \mathrm{~mL} \mathrm{~min}^{-1}$ and shows no extended tailing. A higher residence time promotes more OA retention in the column and pushes the breakthrough point to $\sim 7$ injected pore volumes (PV) compared to $\sim 3$

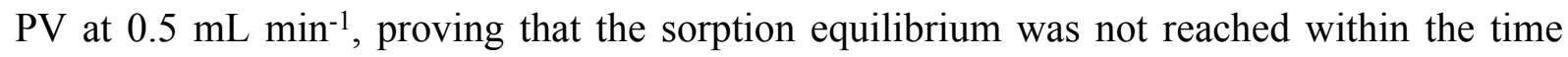
scale of the column experiment. Interestingly, very good agreement between the experimental and calculated breakthrough curves is observed at $0.1 \mathrm{~mL} \mathrm{~min}^{-1}$ (Figure 6b).

In a second experiment, $10 \mu \mathrm{M} \mathrm{OA}$ and $10 \mu \mathrm{M} \mathrm{Cu}^{2+}$ dissolved in synthetic seawater containing $2.3 \mathrm{mM}$ of $\mathrm{NaHCO}_{3}$ (full composition displayed in Table S-3), closer to the real seawater at $\mathrm{pH} 8.2,{ }^{20}$ was injected at $0.5 \mathrm{~mL} \mathrm{~min}^{-1}$. Because of a higher $\mathrm{pH}$ value (Figure $6 \mathrm{a}$ ), lower adsorption and faster breakthrough were obtained, which is in agreement with the batch data. The breakthrough point of OA lies at $1.5 \mathrm{PV}$, while total breakthrough occurs at $\sim 4 \mathrm{PV}$. The predicted breakthrough using batch-derived parameters describes quite well OA transport in the column under salt water conditions and $\mathrm{pH} 8.2$ (Figure 6b). Carbonate-goethite binding was accounted using parameters derived by Rahnemaie et al. ${ }^{49}$ (Figure S-5). This data confirms that transport modeling using hydrodynamic parameters defined by the tracer breakthrough experiment and the surface complexation parameters can be successfully used to predict adsorption of quinolone antibiotics onto goethite under seawater conditions and at two environmentally relevant $\mathrm{pH}$ values (7.4 and 8.2). 

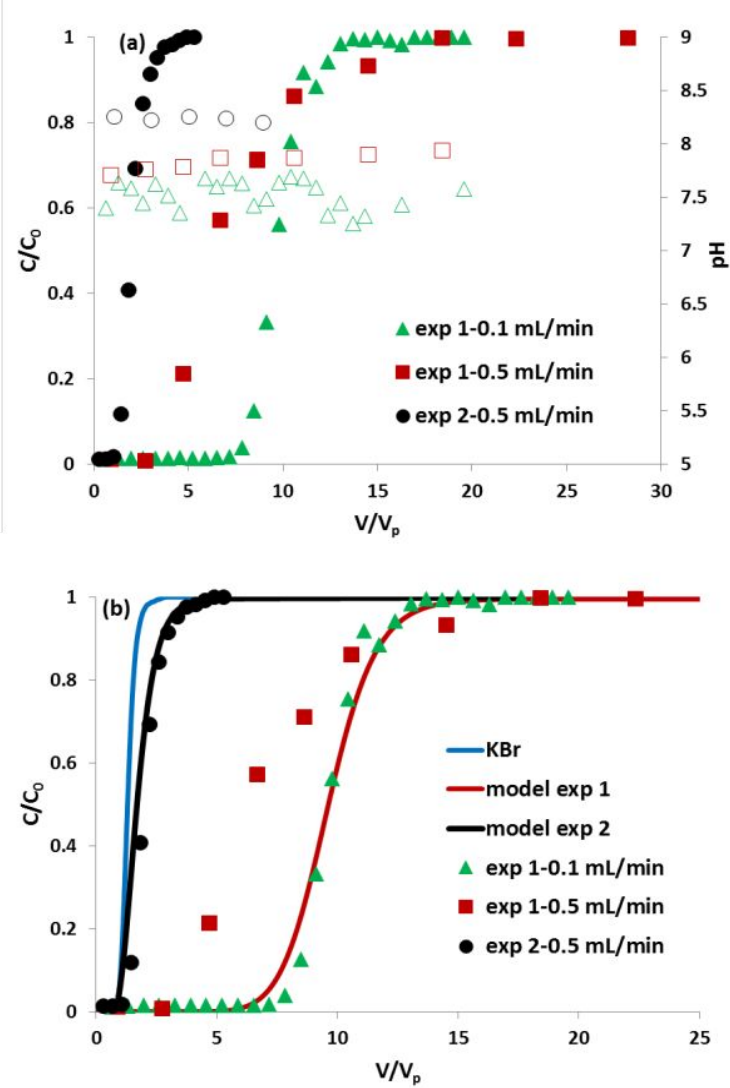

398 Figure 6. (a) Experimental breakthrough curves of OA and pH at two inflow conditions. exp 1: injection of $10 \mu \mathrm{M} \mathrm{OA}$ and $10 \mu \mathrm{M} \mathrm{Cu}^{2+}$ in synthetic seawater. exp 2: injection of $10 \mu \mathrm{M}$ $\mathrm{OA}$ and $10 \mu \mathrm{M} \mathrm{Cu}^{2+}$ in synthetic seawater containing carbonates as for the real seawater (see Table S-3) (b) Calculated BTC of OA and tracer (bromide).

\section{ENVIRONMENTAL IMPLICATIONS}

We have notably demonstrated that TPM can be successfully used to predict adsorption of quinolone antibiotics onto goethite over a large range of environmentally relevant conditions and both under static and flow-through conditions. In addition, the reactive transport of OA can be well simulated through coupling hydrodynamic parameters and surface complexation constants. This modeling approach allowed a quantification of the effects of different ions naturally present in seawater on $\mathrm{OA}$ retention. Although $\mathrm{SO}_{4}{ }^{2-}$ is known as a strong competitor for anions, its effect on OA-goethite binding at seawater relevant $\mathrm{pH}$ was found 
411 almost negligible. Other less abundant ions such as $\mathrm{F}^{-}, \mathrm{Br}^{-}, \mathrm{BO}_{3}{ }^{3-}$ and $\mathrm{Ca}^{2+}$ did not exhibit a

412 significant impact. However, at seawater relevant concentrations, $\mathrm{Mg}^{2+}$ was found to strongly

413 reduce OA-goethite binding via the formation of aqueous complex with OA. Furthermore,

414 trace metals (e.g. $\mathrm{Cu}^{2+}$ used here as a model metal) naturally occurring in seawater could

415 strongly increase OA binding by forming a ternary metal-ligand surface complex. It is worth

416 noting that the presence of natural organic matter in marine and/or estuary ecosystems could

417 also alter the binding mechanism of quinolones onto minerals and then their mobility in

418 marine ecosystems. This last point stresses the need for a more detailed study to assess the

419 application of surface complexation model (SCM) in real seawater containing natural organic

420 matter. These findings may have strong implications in the prediction of transport of

421 quinolones antibiotics, and thus assessment of ecological impacts of aquaculture induced

422 pollution in marine systems.

\section{SUPPORTING INFORMATION}

Thermodynamic calculations of OA solubility and sorption in $480 \mathrm{Mm} \mathrm{NaCl}$; modeling tests of $\mathrm{OA}$ and/or $\mathrm{Cu}^{2+}$ adsorption under different conditions; simulations of carbonate binding to goethite.

\section{ACKNOWLEDGMENTS}

This work was supported by Région Bretagne (K.H). We gratefully acknowledge the Chinese Scholarship Council of PR China for providing financial support for Wei Cheng to stay at the ENSCR.

\section{REFERENCES}

(1) Samuelsen, O. B.; Ervik, A.; Pursell, L.; Smith, P. Single-Dose Pharmacokinetic Study of Oxolinic Acid and Vetoquinol, an Oxolinic Acid Ester, in Atlantic Salmon (Salmosalar) Held in Seawater and in Vitro Antibacterial Activity against Aeromonassalmonicida. Aquaculture 2000, 187 (3), 213-224. https://doi.org/10.1016/S0044-8486(00)00315-X. 
(2) Samuelsen, O. B.; Bergh, Ø.; Ervik, A. A Single-Dose Pharmacokinetic Study of Oxolinic Acid and Vetoquinol, an Oxolinic Acid Ester, in Cod, Gadus Morhua L., Held in Sea Water at $8{ }^{\circ} \mathrm{C}$ and in Vitro Antibacterial Activity of Oxolinic Acid against Vibrio Anguillarum Strains Isolated from Diseased Cod. J. Fish Dis. 2003, 26 (6), 339-347. https://doi.org/10.1046/j.13652761.2003.00466.X.

(3) Picó, Y.; Andreu, V. Fluoroquinolones in Soil-Risks and Challenges. Anal. Bioanal. Chem. 2007, 387 (4), 1287-1299. https://doi.org/10.1007/s00216-006-0843-1.

(4) Rigos, G.; Nengas, I.; Alexis, M.; Troisi, G. M. Potential Drug (Oxytetracycline and Oxolinic Acid) Pollution from Mediterranean Sparid Fish Farms. Aquat. Toxicol. 2004, 69 (3), 281-288. https://doi.org/10.1016/j.aquatox.2004.05.009.

(5) Le, T. X.; Munekage, Y. Residues of Selected Antibiotics in Water and Mud from Shrimp Ponds in Mangrove Areas in Viet Nam. Mar. Pollut. Bull. 2004, 49 (11), 922-929.

https://doi.org/10.1016/j.marpolbul.2004.06.016.

(6) Samuelsen, O. B. Pharmacokinetics of Quinolones in Fish: A Review. Aquaculture 2006, 255 (1-4), 55-75. https://doi.org/10.1016/j.aquaculture.2005.12.008.

(7) Cabello, F. C. Heavy Use of Prophylactic Antibiotics in Aquaculture: A Growing Problem for Human and Animal Health and for the Environment. Environ. Microbiol. 2006, 8 (7), 11371144. https://doi.org/10.1111/j.1462-2920.2006.01054.x.

(8) Marsac, R.; Martin, S.; Boily, J.-F.; Hanna, K. Oxolinic Acid Binding at Goethite and Akaganéite Surfaces: Experimental Study and Modeling. Environ. Sci. Technol. 2016, 50 (2), 660-668. https://doi.org/10.1021/acs.est.5b04940.

(9) Liu, H.; Chen, T.; Frost, R. L. An Overview of the Role of Goethite Surfaces in the Environment. Chemosphere 2014, 103, 1-11. https://doi.org/10.1016/j.chemosphere.2013.11.065.

(10) Timmers, K.; Sternglanz, R. Ionization and Divalent Cation Dissociation Constants of Nalidixic and Oxolinic Acids. Bioinorg. Chem. 1978, 9 (2), 145-155.

(11) Park, H. R.; Jeong, G. Y.; Lee, H. C.; Lee, J. G.; Baek, G. M. Ionization and Divalent Cation Complexation of Quinolone Antibiotics in Aqueous Solution. Bull. Korean Chem. Soc. 2000, $21(9), 849-854$.

(12) Kong, X.; Feng, S.; Zhang, X.; Li, Y. Effects of Bile Salts and Divalent Cations on the Adsorption of Norfloxacin by Agricultural Soils. J. Environ. Sci. 2014, 26 (4), 846-854. https://doi.org/10.1016/S1001-0742(13)60480-5.

(13) Balistrieri, L. S.; Murray, J. W. The Influence of the Major Ions of Seawater on the Adsorption of Simple Organic Acids by Goethite. Geochim. Cosmochim. Acta 1987, 51 (5), 1151-1160.

(14) Pei, Z.; Shan, X.-Q.; Kong, J.; Wen, B.; Owens, G. Coadsorption of Ciprofloxacin and Cu(II) on Montmorillonite and Kaolinite as Affected by Solution PH. Environ. Sci. Technol. 2010, 44 (3), 915-920. https://doi.org/10.1021/es902902c.

(15) Figueroa, R. A.; Leonard, A.; MacKay, A. A. Modeling Tetracycline Antibiotic Sorption to Clays. Environ. Sci. Technol. 2004, 38 (2), 476-483. https://doi.org/10.1021/es0342087.

(16) Wang, Y.-J.; Jia, D.-A.; Sun, R.-J.; Zhu, H.-W.; Zhou, D.-M. Adsorption and Cosorption of Tetracycline and Copper(II) on Montmorillonite as Affected by Solution PH. Environ. Sci. Technol. 2008, 42 (9), 3254-3259. https://doi.org/10.1021/es702641a.

(17) Gaboriaud, F.; Ehrhardt, J.-J. Effects of Different Crystal Faces on the Surface Charge of Colloidal Goethite $(\alpha-\mathrm{FeOOH})$ Particles: An Experimental and Modeling Study. Geochim. Cosmochim. Acta 2003, 67 (5), 967-983.

(18) Hanna, K.; Martin, S.; Quilès, F.; Boily, J.-F. Sorption of Phthalic Acid at Goethite Surfaces under Flow-Through Conditions. Langmuir 2014, 30 (23), 6800-6807. https://doi.org/10.1021/la4049715.

(19) Ross, D. L.; Riley, C. M. Aqueous Solubilities of Some Variously Substituted Quinolone Antimicrobials. Int. J. Pharm. 1990, 63 (3), 237-250. https://doi.org/10.1016/03785173(90)90130-V.

(20) Kester, D. R.; Duedall, I. W.; Connors, D. N.; Pytkowicz, R. M. Preparation of Artificial Seawater1. Limnol. Oceanogr. 1967, 12 (1), 176-179. https://doi.org/10.4319/1o.1967.12.1.0176. 
(21) Hanna, K.; Boily, J.-F. Sorption of Two Naphthoic Acids to Goethite Surface under Flow through Conditions. Environ. Sci. Technol. 2010, 44 (23), 8863-8869. https://doi.org/10.1021/es102903n.

(22) Hiemstra, T.; Van Riemsdijk, W. H. A Surface Structural Approach to Ion Adsorption: The Charge Distribution (CD) Model. J. Colloid Interface Sci. 1996, 179 (2), 488-508.

(23) Parkhurst, D. L.; Appelo, C. A. J. User's Guide to PHREEQC (Version 2): A Computer Program for Speciation, Batch-Reaction, One-Dimensional Transport, and Inverse Geochemical Calculations. 1999.

(24) Kinniburgh, D.; Cooper, D. PhreePlot: Creating graphical output with PHREEQC http://www.phreeplot.org/PhreePlot.pdf (accessed Aug 29, 2018).

(25) Parkhurst, D. L. Ion-Association Models and Mean Activity Coefficients of Various Salts. In Chemical Modeling of Aqueous Systems II; ACS Symposium Series; American Chemical Society, 1990; Vol. 416, pp 30-43. https://doi.org/10.1021/bk-1990-0416.ch003.

(26) Grenthe, I.; Plyasunov, A. V.; Spahiu, K. Estimations of Medium Effects on Thermodynamic Data. Model. Aquat. Chem. 1997, 325-426.

(27) Stachowicz, M.; Hiemstra, T.; van Riemsdijk, W. H. Multi-Competitive Interaction of As(III) and $\mathrm{As}(\mathrm{V})$ Oxyanions with $\mathrm{Ca} 2+, \mathrm{Mg} 2+, \mathrm{PO} 3-4$, and $\mathrm{CO} 2-3$ Ions on Goethite. J. Colloid Interface Sci. 2008, 320 (2), 400-414. https://doi.org/10.1016/j.jcis.2008.01.007.

(28) Boily, J.-F.; Persson, P.; Sjöberg, S. Benzenecarboxylate Surface Complexation at the Goethite $(\alpha-\mathrm{FeOOH}) /$ Water Interface: II. Linking IR Spectroscopic Observations to Mechanistic Surface Complexation Models for Phthalate, Trimellitate, and Pyromellitate. Geochim. Cosmochim. Acta 2000, 64 (20), 3453-3470.

(29) Boily, J.-F.; Kozin, P. A. Particle Morphological and Roughness Controls on Mineral Surface Charge Development. Geochim. Cosmochim. Acta 2014, 141, 567-578. https://doi.org/10.1016/j.gca.2014.06.016.

(30) Rietra, R. P. J. J.; Hiemstra, T.; van Riemsdijk, W. H. Comparison of Selenate and Sulfate Adsorption on Goethite. J. Colloid Interface Sci. 2001, 240 (2), 384-390. https://doi.org/10.1006/jcis.2001.7650.

(31) Fukushi, K.; Sverjensky, D. A. A Surface Complexation Model for Sulfate and Selenate on Iron Oxides Consistent with Spectroscopic and Theoretical Molecular Evidence. Geochim. Cosmochim. Acta 2007, 71 (1), 1-24. https://doi.org/10.1016/j.gca.2006.08.048.

(32) Hinkle, M. A. G.; Wang, Z.; Giammar, D. E.; Catalano, J. G. Interaction of Fe(II) with Phosphate and Sulfate on Iron Oxide Surfaces. Geochim. Cosmochim. Acta 2015, 158, 130-146. https://doi.org/10.1016/j.gca.2015.02.030.

(33) Johnston, C. P.; Chrysochoou, M. Mechanisms of Chromate, Selenate, and Sulfate Adsorption on Al-Substituted Ferrihydrite: Implications for Ferrihydrite Surface Structure and Reactivity. Environ. Sci. Technol. 2016, 50 (7), 3589-3596. https://doi.org/10.1021/acs.est.5b05529.

(34) Boukhalfa, C. Sulfate Removal from Aqueous Solutions by Hydrous Iron Oxide in the Presence of Heavy Metals and Competitive Anions. Desalination 2010, 250 (1), 428-432. https://doi.org/10.1016/j.desal.2009.09.070.

(35) Peak, D.; Ford, R. G.; Sparks, D. L. An in Situ ATR-FTIR Investigation of Sulfate Bonding Mechanisms on Goethite. J. Colloid Interface Sci. 1999, 218 (1), 289-299. https://doi.org/10.1006/jcis.1999.6405.

(36) Wijnja, H.; Schulthess, C. P. Vibrational Spectroscopy Study of Selenate and Sulfate Adsorption Mechanisms on Fe and $\mathrm{Al}$ (Hydr)Oxide Surfaces. J. Colloid Interface Sci. 2000, 229 (1), 286-297. https://doi.org/10.1006/jcis.2000.6960.

(37) Rahnemaie, R.; Hiemstra, T.; van Riemsdijk, W. H. Inner- and Outer-Sphere Complexation of Ions at the Goethite-Solution Interface. J. Colloid Interface Sci. 2006, 297 (2), 379-388. https://doi.org/10.1016/j.jcis.2005.11.003.

(38) Weng, L.; Van Riemsdijk, W. H.; Hiemstra, T. Cu2+ and Ca2+adsorption to Goethite in the Presence of Fulvic Acids. Geochim. Cosmochim. Acta 2008, 72 (24), 5857-5870. https://doi.org/10.1016/j.gca.2008.09.015.

(39) Gu, X.; Tan, Y.; Tong, F.; Gu, C. Surface Complexation Modeling of Coadsorption of Antibiotic Ciprofloxacin and $\mathrm{Cu}(\mathrm{II})$ and onto Goethite Surfaces. Chem. Eng. J. 2015, 269, $113-$ 120. https://doi.org/10.1016/j.cej.2014.12.114. 
(40) Guaita, D. P.; Sayen, S.; Boudesocque, S.; Guillon, E. Copper(II) Influence on Flumequine Retention in Soils: Macroscopic and Molecular Investigations. J. Colloid Interface Sci. 2011, 357 (2), 453-459. https://doi.org/10.1016/j.jcis.2011.01.097.

(41) Ali, M. A.; Dzombak, D. A. Effects of Simple Organic Acids on Sorption of Cu2+ and Ca2+ on Goethite. Geochim. Cosmochim. Acta 1996, 60 (2), 291-304.

(42) Fein, J. B. The Effects of Ternary Surface Complexes on the Adsorption of Metal Cations and Organic Acids onto Mineral Surfaces. In: R. Hellmann and S.A. Wood (Editors), Water-Rock Interactions, Ore Deposits, and Environmental Geochemistry: A Tribute to David A. Crerar. Geochemical Society, Special Pub. 7, pp. 365-378.

(43) Swedlund, P. J.; Webster, J. G.; Miskelly, G. M. Goethite Adsorption of Cu(II), Pb(II), Cd(II), and $\mathrm{Zn}(\mathrm{II})$ in the Presence of Sulfate: Properties of the Ternary Complex. Geochim. Cosmochim. Acta 2009, 73 (6), 1548-1562. https://doi.org/10.1016/j.gca.2008.12.007.

(44) Hiemstra, T.; Van Riemsdijk, W. H. Fluoride Adsorption on Goethite in Relation to Different Types of Surface Sites. J. Colloid Interface Sci. 2000, 225 (1), 94-104. https://doi.org/10.1006/jcis.1999.6697.

(45) Porro, I.; Newman, M. E.; Dunnivant, F. M. Comparison of Batch and Column Methods for Determining Strontium Distribution Coefficients for Unsaturated Transport in Basalt. Environ. Sci. Technol. 2000, 34 (9), 1679-1686. https://doi.org/10.1021/es9901361.

(46) Altfelder, S.; Streck, T.; Maraqa, M. A.; Voice, T. C. Nonequilibrium Sorption of Dimethylphthalate - Compatibility of Batch and Column Techniques. Soil Sci. Soc. Am. J. 2001, 65 (1), 102-111. https://doi.org/10.2136/sssaj2001.651102x.

(47) Hanna, K.; Lassabatere, L.; Bechet, B. Transport of Two Naphthoic Acids and Salicylic Acid in Soil: Experimental Study and Empirical Modeling. Water Res. 2012, 46 (14), 4457-4467. https://doi.org/10.1016/j.watres.2012.04.037.

(48) Hanna, K.; Rusch, B.; Lassabatere, L.; Hofmann, A.; Humbert, B. Reactive Transport of Gentisic Acid in a Hematite-Coated Sand Column: Experimental Study and Modeling. Geochim. Cosmochim. Acta 2010, 74 (12), 3351-3366. https://doi.org/10.1016/j.gca.2010.03.022.

(49) Rahnemaie, R.; Hiemstra, T.; van Riemsdijk, W. H. Carbonate Adsorption on Goethite in Competition with Phosphate. J. Colloid Interface Sci. 2007, 315 (2), 415-425. https://doi.org/10.1016/j.jcis.2007.07.017. 
581

\begin{tabular}{|c|c|c|c|c|c|}
\hline Aqueous solutions & $\log K$ & & $\mathbf{b}_{\mathbf{i}}$ & & ref. \\
\hline $\mathrm{OAH}_{(\mathrm{s})} \rightleftharpoons \mathrm{OAH}_{(\mathrm{aq})}$ & -5.06 & & 0 & & 8 \\
\hline $\mathrm{OA}^{-}+\mathrm{H}^{+} \rightleftharpoons \mathrm{OAH}$ & 6.92 & & 0 & & 8 \\
\hline $\mathrm{OA}^{-}+\mathrm{Mg}^{+2} \rightleftharpoons \mathrm{OAMg}^{+}$ & 3.51 & & $0.5 \pm 0.1$ & & 10 \\
\hline $\mathrm{OA}^{-}+\mathrm{Cu}^{+2} \rightleftharpoons \mathrm{OACu}^{+}$ & 6.61 & & $0.5\left(\mathrm{~b}_{\text {OAMg }}{ }^{+}\right)$ & & 10 \\
\hline $\mathrm{OA}^{-}+\mathrm{Ca}^{+2} \rightleftharpoons \mathrm{OACa}^{+}$ & 2.61 & & $0.5\left(\mathrm{~b}_{\text {OAMg }}{ }^{+}\right)$ & & 10 \\
\hline Surface reactions & $\log K$ & $\Delta \mathrm{z}_{0}$ & $\Delta \mathrm{z}_{1}$ & $\Delta \mathbf{z}_{2}$ & \\
\hline$\equiv \mathrm{Fe}_{3} \mathrm{O}^{-0.5}+\mathrm{H}^{+} \rightleftharpoons \equiv \mathrm{Fe}_{3} \mathrm{OH}^{+0.5}$ & 9.1 & +1 & 0 & 0 & 8 \\
\hline$\equiv \mathrm{Fe}_{3} \mathrm{O}^{-0.5}+\mathrm{H}^{+}+\mathrm{Cl}^{-} \rightleftharpoons \equiv \mathrm{Fe}_{3} \mathrm{OH}_{2}{ }^{+0.5 \cdots \mathrm{Cl}^{-}}$ & 8.1 & +1 & 0 & -1 & 8 \\
\hline$\equiv \mathrm{Fe}_{3} \mathrm{O}^{-0.5}+\mathrm{Na}^{+} \rightleftharpoons \equiv \mathrm{Fe}_{3} \mathrm{OH}^{-0.5 \cdots \mathrm{Na}^{+}}$ & -1 & 0 & 0 & +1 & 8 \\
\hline$\equiv \mathrm{FeOH}^{-0.5}+\mathrm{H}^{+} \rightleftharpoons \equiv \mathrm{FeOH}_{2}^{+0.5}$ & 9.1 & +1 & 0 & 0 & 8 \\
\hline$\equiv \mathrm{FeOH}^{-0.5}+\mathrm{H}^{+}+\mathrm{Cl}^{-} \rightleftharpoons \equiv \mathrm{FeOH}_{2}{ }^{+0.5 \cdots \mathrm{Cl}^{-}}$ & 8.1 & +1 & 0 & -1 & 8 \\
\hline$\equiv \mathrm{FeOH}^{-0.5}+\mathrm{Na}^{+} \rightleftharpoons \equiv \mathrm{FeOH}^{-0.5 \ldots} \mathrm{Na}^{+}$ & -1 & 0 & 0 & +1 & 8 \\
\hline $2 \mathrm{H}^{+}+2 \equiv \mathrm{FeOH}^{-0.5}+\mathrm{OA}^{-} \rightleftharpoons(\equiv \mathrm{Fe})_{2}(\mathrm{OA})^{0}+2 \mathrm{H}_{2} \mathrm{O}$ & $20.6 \pm 0.1$ & +1 & 0 & 0 & 8 \\
\hline $2 \mathrm{H}^{+}+2 \equiv \mathrm{FeOH}^{-0.5}+\mathrm{OA}^{-} \rightleftharpoons\left(\equiv \mathrm{FeOH}_{2}\right)_{2}{ }^{+\cdots} \mathrm{OA}^{-}$ & $20.6 \pm 0.1$ & +1.6 & -0.6 & 0 & 8 \\
\hline $2 \equiv \mathrm{FeOH}^{-0.5}+\mathrm{Mg}^{+2} \rightleftharpoons(\equiv \mathrm{FeOH})_{2} \mathrm{Mg}^{+}$ & 4.89 & +0.71 & +1.29 & 0 & 30 \\
\hline $2 \equiv \mathrm{FeOH}^{-0.5}+\mathrm{Mg}^{+2}+\mathrm{H}_{2} \mathrm{O} \rightleftharpoons(\equiv \mathrm{FeOH})_{2} \mathrm{MgOH}+\mathrm{H}^{+}$ & -6.44 & +0.71 & +0.29 & 0 & 30 \\
\hline$\equiv \mathrm{FeOH}^{-0.5}+\mathrm{Ca}^{+2} \rightleftharpoons \equiv \mathrm{FeOHCa}^{+1.5}$ & 2.85 & 0 & +2 & 0 & 30 \\
\hline$\equiv \mathrm{Fe}_{3} \mathrm{O}^{-0.5}+\mathrm{Ca}^{+2} \rightleftharpoons \equiv \mathrm{Fe}_{3} \mathrm{OCa}^{+1.5}$ & 2.85 & 0 & +2 & 0 & 30 \\
\hline$\equiv \mathrm{FeOH}^{-0.5}+\mathrm{Ca}^{+2} \rightleftharpoons \equiv \mathrm{FeOHCa}^{+1.5}$ & 3.69 & +0.32 & +1.68 & 0 & 30 \\
\hline$\equiv \mathrm{FeOH}^{-0.5}+\mathrm{Ca}^{+2}+\mathrm{H}_{2} \mathrm{O} \rightleftharpoons \equiv \mathrm{FeOHCaOH}^{+1.5}+\mathrm{H}^{+}$ & -9.17 & +0.32 & +0.68 & 0 & 30 \\
\hline $\mathrm{H}^{+}+\equiv \mathrm{FeOH}^{-0.5}+\mathrm{SO}_{4}^{-2} \rightleftharpoons(\equiv \mathrm{Fe})\left(\mathrm{SO}_{4}\right)^{1.5-}+\mathrm{H}_{2} \mathrm{O}$ & $8.0 \pm 0.2 *(9.37)$ & +0.5 & -1.5 & 0 & 37 \\
\hline $\mathrm{H}^{+}+\equiv \mathrm{FeOH}^{-0.5}+\mathrm{SO}_{4}^{-2} \rightleftharpoons(\equiv \mathrm{Fe})\left(\mathrm{SO}_{4}\right)^{1.5-\cdots} \mathrm{H}_{2} \mathrm{O}$ & $9.7 \pm 0.2 *(11.06)$ & +1 & -1.84 & -0.16 & 37 \\
\hline $2 \equiv \mathrm{FeOH}^{-0.5}+\mathrm{Cu}^{+2} \rightleftharpoons(\equiv \mathrm{FeOH})_{2} \mathrm{Cu}^{+}$ & 9.18 & +0.84 & +1.16 & 0 & 38 \\
\hline $2 \equiv \mathrm{FeOH}^{-0.5}+\mathrm{Cu}^{+2}+\mathrm{H}_{2} \mathrm{O} \rightleftharpoons(\equiv \mathrm{FeOH})_{2} \mathrm{CuOH}+\mathrm{H}^{+}$ & $4.6 \pm 0.1 *(3.6)$ & +0.84 & +0.16 & 0 & 38 \\
\hline $2 \equiv \mathrm{FeOH}^{-0.5}+2 \mathrm{Cu}^{+2}+2 \mathrm{H}_{2} \mathrm{O} \rightleftharpoons(\equiv \mathrm{FeOH})_{2} \mathrm{Cu}_{2}(\mathrm{OH})_{2}{ }^{+}+2 \mathrm{H}^{+}$ & 3.65 & +0.84 & +1.16 & 0 & 38 \\
\hline $2 \equiv \mathrm{FeOH}^{-0.5}+2 \mathrm{Cu}^{+2}+3 \mathrm{H}_{2} \mathrm{O} \rightleftharpoons(\equiv \mathrm{FeOH})_{2} \mathrm{Cu}_{2}(\mathrm{OH})_{3}+3 \mathrm{H}^{+}$ & -3.1 & +0.84 & +0.16 & 0 & 38 \\
\hline $2 \equiv \mathrm{FeOH}^{-0.5}+\mathrm{OA}^{-}+\mathrm{Cu}^{+2} \rightleftharpoons(\equiv \mathrm{FeOH})_{2} \mathrm{CuOA}$ & $18 \pm 0.1$ & +1.3 & -0.3 & 0 & P.W. \\
\hline $2 \equiv \mathrm{FeOH}^{-0.5}+\mathrm{Cu}^{+2}+\mathrm{SO}_{4}^{-2} \rightleftharpoons(\equiv \mathrm{FeOH})_{2} \mathrm{CuSO}_{4}^{-}$ & $12.6 \pm 0.2$ & +1.5 & -1.5 & 0 & P.W. \\
\hline$\equiv \mathrm{FeOH}^{-0.5}+\mathrm{H}^{+}+\mathrm{F}^{-} \rightleftharpoons \equiv \mathrm{FeF}^{-0.5}+\mathrm{H}_{2} \mathrm{O}$ & 9.6 & +0.4 & -0.4 & 0 & 44 \\
\hline $2 \mathrm{H}^{+}+2 \equiv \mathrm{FeOH}^{-0.5}+\mathrm{CO}_{3}^{-2} \rightleftharpoons(\equiv \mathrm{Fe})_{2}\left(\mathrm{CO}_{3}\right)^{-1}+2 \mathrm{H}_{2} \mathrm{O}$ & 22.01 & +0.62 & -0.62 & 0 & 49 \\
\hline $2 \mathrm{H}^{+}+2 \equiv \mathrm{FeOH}^{-0.5}+\mathrm{CO}_{3}^{-2}+\mathrm{Na}^{+} \rightleftharpoons(\equiv \mathrm{Fe})_{2}\left(\mathrm{CO}_{3} \mathrm{Na}\right)^{0}+2 \mathrm{H}_{2} \mathrm{O}$ & 22.03 & +0.62 & +0.38 & 0 & 49 \\
\hline $\mathrm{H}^{+}+\equiv \mathrm{FeOH}^{-0.5}+\mathrm{CO}_{3}^{-2} \rightleftharpoons \equiv \mathrm{FeOH}_{2} \mathrm{CO}_{3}^{-1.5}$ & 10.22 & +1 & -2 & 0 & 49 \\
\hline $\mathrm{H}^{+}+\equiv \mathrm{Fe}_{3} \mathrm{O}^{-0.5}+\mathrm{CO}_{3}^{-2} \rightleftharpoons \equiv \mathrm{Fe}_{3} \mathrm{OHCO}_{3}^{-1.5}$ & 10.22 & +1 & -2 & 0 & 49 \\
\hline
\end{tabular}

582 *adjusted from the original work. Log $\mathrm{K}$ values are given at $\mathrm{I}=0$. Parameter " $\mathrm{b}_{\mathrm{i}}$ " is used in the

583 WATEQ equation. The original constants from literature are in the brackets. 
586

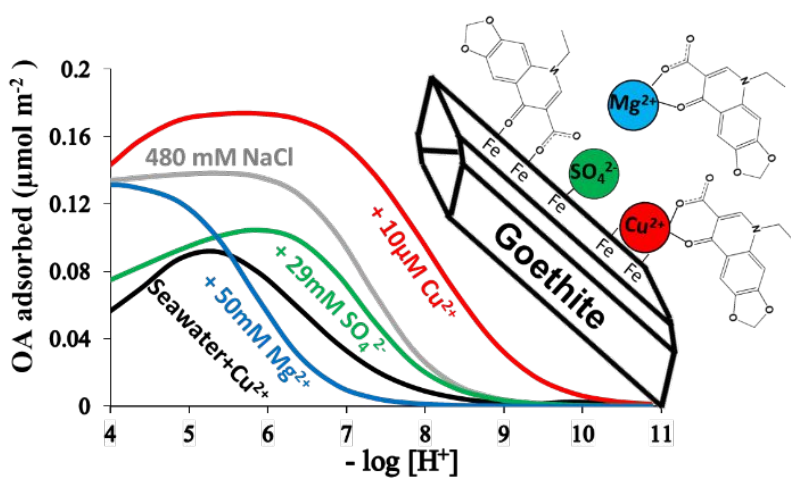

